\title{
Combating Corruption in Yudhoyono's Indonesia: An Insider's Perspective1
}

\section{DENNY INDRAYANA}

Faculty of Law, University of Gadjah Mada, Visiting Professor at the Melbourne Law School and Faculty of Arts - University of Melbourne

denny.indrayana@unimelb.edu.au

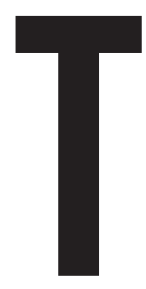

his paper shares my experiences in combating corruption under President Susilo Bambang Yudhoyono's (SBY) administration from 2004 to 2014. In particular, I want to give you my inside story as President SBY's Special Advisor for Legal Affairs from 2008 to 2009; his Special Advisor for Legal Affairs, Human Rights, and Anti-Corruption from 2009 to 2011; and his Deputy Minister for Law and Human Rights from 2011 to 2014. I hope my experience of six years in government that I will share with you tonight may be of some use in building a better understanding of how difficult is to combat corruption, even for the strongest authority in the country, the President.

I should admit that my observations may be subjective, because of my close relationship with Pak SBY, but I can guarantee that I will try my best to give you an academic and objective overview of the anticorruption agenda under his administration. I will leave it to you

1 This paper has never been published but was presented on my inauguration as Visiting Professor in the University of Melbourne on the 20 September 2016. 
to decide how successful I am in doing this! If you disagree with me, it does not matter. In fact, disagreeing is better, so we can have more fruitful discussions!

\section{THE PRESIDENT AFTER REFORMASI: A MORE CHALLENGING JOB}

Let me begin by sharing with you my argument that to be an effective president one should have at least three things: more constitutional powers, strong political support, and sufficient control. I first delivered this argument in my inauguration speech as professor of constitutional law in the Faculty of Law of the University of Gadjah Mada in 2011. To put it in mathematical terms, my argument is:

$$
\begin{aligned}
& \mathrm{EP}=\mathrm{CP}+\mathrm{PS}+\mathrm{C} \\
& \mathrm{EP}=\text { Effective Presidency } \\
& \mathrm{CP}=\text { Constitutional Powers } \\
& \mathrm{PS}=\text { Political Support } \\
& \mathrm{C}=\text { Control }
\end{aligned}
$$

By 'constitutional powers', I mean the authority that a president has, as outlined in the constitution. The more he has, the more effective a president become, and vice versa. It is not difficult to conclude that the president after the reformasi, especially after the four constitutional amendments made between 199 and 2002, is constitutionally a weaker president. The 1945 Constitution used to be called as an "executive heavy constitution", meaning that the constitution give more powers to the president compared to the other branches. The amendments mean it has become a more limited executive constitution, with more checks and balances. One example of the impact of the amendment is the limitation of presidential term, previously unlimited, to a maximum of two terms, or ten years. This amendment is crucial to save Indonesia from experiencing another president for life, or at least one ruling for more than 30 years as Soeharto did during the New Order era.

Second, 'political support' here means mainly support from political parties, especially those who have seats or members in the parliament, that is, the House of Representatives (DPR). With more limited powers, the post- reformasi Presidents have serious problems with political support. None of the presidents since the reformasi have led a party that enjoys a majority in the DPR. The situation is 
completely different to Soeharto's presidency, where the president's party, GOLKAR, enjoyed an, on average, 68.5\% majority in the DPR. In fact, none of the parties since the reformasi have been able to win more than $30 \%$ of the national vote, with the only exception being the Struggle Indonesia Democratic Party (PDIP), which won 33.7\% in 1999 election. In the last national election, 2014, PDIP still won the election but did so with just $19.26 \%$ of the vote. To be an effective president, one should gain at least majority support from the House, so as to be able to easily pass laws, make policies and appoint people to strategic positions.

This lack of reliable majority political party support has directly contributed to the difficulties all post-reformasi presidents have faced in leading the country. The president has no option other than to try to establish a solid coalition of parties, which is not always an effective solution. It is, in fact, very challenging. In Bahasa Indonesia I would say, instead of having a coalition that is solid, the president usually ends up with coalition that is sulit (difficult).

My third element is sufficient control. A president with more constitutional power and enough political support may still not be a good president unless there is a sufficient system of control, or checks and balances, not only from the opp osition, but also from the public and the media. In any case, this control factor is the key. A president who is not controlled would be very effective but, at the same time, destructive. A president subject to too much control will be ineffective: he or she will not be able deliver on policies and definitely would find it very difficult to fulfill campaign promises. It is very clear that after reformasi control of the president comes from many directions, among others, a much stronger and sharper DPR, far more active NGOs, and, of course, the media. By contrast, in the New Order era, Soeharto was subject to very limited control, and sometimes almost none.

So, compared to Soekarno and Soeharto, the post-reformasi president faces far more challenges to be an effective ruler. With more limited powers, minority political support and weak coalitions, and many more effective controls on him or her, the president must somehow lead a country like Indonesia, which has so many extremely complex problems, including, of course, corruption, one the root causes of so many other problems. 


\section{PRESIDENT YUDHOYONO AND POLITICAL SUPPORT}

I will now discuss the political support President SBY had. I focus on this factor because it is more dynamic than the other two: constitutional powers and control. Another reason to discuss his political support is that it is one of the key factors in combating corruption in Indonesia. In fact, the political landscape is crucial in determining whether a president's agenda will be successful or not.

Although the numbers were not so different, the effectiveness of political support for Yudhoyono was different between the first and second terms of his presidency. The coalition from 2004 to 2009 consisted of 8 parties, equivalent to $73.3 \%$ of the DPR.

The coalition from 2009 to 2014 was consisted of 6 parties, equivalent to $75.5 \%$ members of the DPR. The votes for Democrat Party increased almost three times, from $7.45 \%$ votes in 2004 to $20.85 \%$ in 2009.

I would argue, however, that, in the end, this increase made no significant difference to the struggle against corruption. According to the numbers - and especially the Democrat Party's basic political capital, which increased almost threefold - Yudhoyono's capacity to combat corruption was supposed to be much stronger. Unfortunately, this proved not to be the case at all.

After winning the 2009 election, President SBY was optimistic about his second term. He told me that the significant increase in the Democrat Party vote is a strong mandate for him to run the government more effectively, including as regards anti-corruption efforts. One thing about which he and I miscalculated was that the increase in his political mandate did result in increased supported from his own coalition. That did not happen. In fact, political attacks in his second term were sometimes more frequent and intense than in his first term. Strangely, these attacks mainly came NOT from the opposition, that is, the PDIP, led by Megawati Soekarnoputri. The most dangerous attacks came, in fact, from within the coalition.

It is clear that coalition support during President SBY's first term was more solid than in his second term. There were many reasons for this. One is Golkar's position. Originally, Golkar had no history of supporting an elected president in the post-reformasi period. They nominated their own candidate, and lost the battle. In 2004, 
not long after he was inaugurated as Vice President, Jusuf Kalla (JK) won the chair of Golkar, and re-positioned the party as a supporter of government. JK and Golkar's significant political experience contributed to the government's political stability and reduced attacks on SBY's first presidency.

The situation was very different in the second term. Golkar again nominated its own candidate and loss the battle in the 2009 presidential election. They also again eventually joined the cabinet and became part of the government coalition. This time, however, Golkar's support was not as strong. Unlike the first term, when the Chair of Golkar was also the Vice President, in the second term, the Chair of Golkar, Aburizal Bakrie, had no position in the government. He was not even a member of the cabinet. The resulting half-hearted support of Golkar had a significant impact to the solidity of parties' coalition. Moreover, the Prosperous Justice Party (PKS), another coalition member, took the same position as Golkar, that is, it only partially supported the President.

In fact, only few months after being inaugurated as members of cabinet and coalition, Golkar and PKS aggressively initiated a Special Committee to investigate Bank Century case, something President SBY did not want to happen. I recently accompanied a former senior minister who visited Melbourne. He told me that he actually advised President SBY to expel both Golkar and PKS from the coalition. I shared his view, but I also understood the dilemma President SBY faced at the time.

I know that President SBY was, on several occasions, very angry and seemed likely to expel Golkar and PKS. But, after making more careful political calculations, he finally decided to keep both parties inside the tent, rather than let them join the opposition, led by PDIP, and make it more stronger and effective, thus creating a very dangerous political risk for his administration. I know, for sure, that this was not an easy decision for SBY-but he had limited options.

Having Boediono as Vice President in his second term gave SBY a big opportunity to strengthen the anticorruption agenda. An academic, not a politician, Pak Boediono was appointed as a technocrat. He therefore had no conflict of interest politically or in terms of business that would make it difficult for him to reinforce good governance and wage war against corruptors. Unfortunately, however, having no formal position in a political party turned out also to be a disadvantage 
for someone holding a strategic political position in Indonesia. In fact, the Bank Century case saw Vice President Boediono and the reformist Minister of Finance, Sri Mulyani, both become political targets, attacked by politicians led by Golkar, PDIP and PKS.

The first six months of the second term of the SBY presidency were very tough. The Bank Century case was always headline news and hearings were broadcast live by almost all television stations, owned by the president's opponents. It was only after President SBY finally allowed Sri Mulyani to resign as Minister to become Managing Director of the World Bank that the attacks slowed down. This showed that the Bank Century case was really more a personal attack than something in the national interest.

During these troubled six months President SBY tried to exercise more powers to combat corruption. Several times he made public statements calling for a fight against anybody who tried to avoid tax payments. I could only guess against which persons and company groups those statements were directed. I think the Indonesia public knew perfectly well who the president was referring to. Despite this, once he lost a vote in the DPR to stop the Bank Century case, President SBY had no option other than to make political compromises.

I remember that on the night of that loss, we were in the State House near the palace monitoring the voting process. President SBY asked a rhetorical question, "What if the government coalition only consisted of three parties". I assumed he was referring to the Democrat Party, the National Mandate Party (PKB) and the National Awakening Party (PKB), who fully supported his position in the Bank Century case in the DPR. He paused and then added, "It is not good to make decision when you are full of anger". Two weeks after that, in a very small meeting of just a few participants held at his house in Cikeas, SBY explained that he had finally decided to step back a little bit, to decrease political tensions and focus more on the economic agenda. It was after that meeting that the so-called Joint Secretariat of Coalition was established and Aburizal Bakrie became its head.

This six months of Bank Century battles constituted clear evidence that the war against corruption would not be successful without a clean political landscape. Even a president with a strong mandate will always have to make very careful calculations if he or she wants to pursue an anticorruption agenda.

Another lesson from SBY's two terms was that the strength of 
his political support was related in complex ways to stability of the government and the progress of anticorruption efforts. I would argue that the first term of his presidency was more stable. Political support for President SBY and Vice President JK was more solid than for SBY and Boediono. 'Stable', however, does not mean less corrupt. The New Order of Soeharto is a clear example of a more stable administration that was actually very corrupt. In fact, if you seriously want to combat corruption in a very corrupt political landscape, the political situation will certainly NOT be stable. The problem of maintaining political stability and at the same time combating corruption is the primary challenge of any leader of a corrupt country, and the Indonesian president is not excluded from that test.

Moreover, in Indonesia, political support is not necessarily positive, particularly because political parties are still part of the problem-and not the solution-for anticorruption efforts. To make the situation worse, the parties are usually closely linked with corrupt businessmen who support them financially. This financial support means the parties lack independence and are easily contaminated by corrupt practices and vested interests. Regrettably, the numbers of tycoons, or as we say, 'konglomerat' who support the parties are not many, and therefore, Indonesian parties are easily influenced by small number of powerful oligarchs who have access to the parties', and the country's, top leaders.

In fact, according to the latest report of World Bank, Indonesia ranks as the world's third worst concentration of wealth, where only $10 \%$ own $77 \%$, or $1 \%$ own $50.3 \%$ of the country's wealth. Further, according the Economist, Indonesia ranks as seventh worst in cronycapitalism index, where about two-third of the richest Indonesian run their business with the support of the authorities, or in collusion with them. This situation makes the anti-corruption agenda even more difficult. One way to solve the problem is by reforming the financial systems of political parties, so they are more independent and not so easily contaminated by the intervention of corrupt businessmen.

\section{PRESIDENT SBY AND ANTI-CORRUPTION A GENDA}

I joined the palace in late 2008, only one year before President SBY finished his first term but I learned a lot about his approach 
to combating corruption in his early years. One of the very first instructions issued by President Yudhoyono was on corruption eradication acceleration. I understand why some of the anticorruption NGOs criticized this instruction as ineffective but it was at least a clear and strong gesture by a President who wanted to put anti-corruption on his priority agenda.

'Ineffective' was also the term used by his critics to describe SBY's initiative to set up a Coordinating Team to combat corruption. Indonesia Corruption Watch was suspicious that the team would be a rival - and a threat - to the Corruption Eradication Commission (KPK). I also criticized that Coordinating team, argued the President should instead support and strengthen the KPK. However, I now think that what the President tried to establish could actually be a good idea - we need a better coordination system among the police and public prosecution service, especially in handling corruption cases.

Another important initiative in relation to anti-corruption was when President SBY sought to implement the Law on Military, prohibiting the Indonesia National Army (TNI) from carrying on business. The President set up a team to prepare the transfer of TNI businesses to a more legitimate format. This initiative was not widely covered by the media, but was it actually a very good and important initiative.

President SBY's approach of setting up ad hoc committees to execute his anticorruption agenda actually showed how complex the problems are. Pak SBY is a very disciplined and correct person who always works according to the constitution and regulations. In fact, one of his habits is to always carry a copy of the constitution, signed with his name, in his pocket. Therefore to ask him to make a decision that did not accord with the written laws is impossible. He nonetheless accept my advice to set up some ad hoc committees to deal with corruption issues, even if their legal basis was not always strong.

Two of these committees were the Task Force to Eradicate Judicial Mafia and Independent Team to Investigate Chandra Hamzah and Bibid Samad Riyanto, the two commissioners of KPK. These ad hoc committees were direct responses to the conflict between KPK and corrupt policemen. There were three big conflicts of this kind - in 2009, 2012 and most recently in 2015. I would like to share with you how President SBY handled the conflict against KPK in 2009 and 
2012. I will not discuss the third conflict in 2015 , because it was not under SBY's administration, the timeframe of our discussion. I will also avoid it because it will inevitably involve my own subjective views as I was named a corruption suspect mainly because I strongly and publicly supported the KPK in this third battle with the corrupt police.

\section{PRESIDENT SBY AND SUPPORT FOR THE KPK}

Almost every time President SBY needed to communicate with the KPK, he would ask me to contact its leaders. The President knew very well that KPK is an independent body that is not under the control of his executive branch but he also knew that informal but respectful communication is always important. One principle that SBY kept mentioning to me was that communication should not be an intervention in KPK, preventing them from doing their job of eradicating corruption. Indeed, the President did not seek to prevent the KPK from investigating corruption cases against Aulia Pohan, the father-in-law of his eldest son. SBY also never used his presidential powers to try to stop cases against leaders of his own Democrat Party, despite the damage these investigations did to his party.

Interventions in legal case are clearly prohibited according to SBY's principles. Yet, I did manage to ask the President to rescue the KPK from being attacked by corruptors. In late 2009, almost at the same time the Century case was initiated by the DPR, two commissioners of the KPK, Chandra Hamzah and Samad Riyanto, were named as suspects by the Indonesian police. This case quickly became an open conflict between KPK and corrupt police. Civil society intensively and extensively launched a public campaign under the tag of 'gecko versus crocodile' (Cicak Vs Buaya), to show their support from KPK, which was symbolized as the gecko, with corrupt police as the crocodile. Ironically, the gecko and crocodile image was first suggested by Susno Duadji, a three star police general, in an interview with Tempo magazine to show the KPK had no chance against the police.

I believed that the cases against the two KPK commissioners were fabricated. Based on this and inputs from anti-corruption colleagues, I suggested President SBY set up an independent team to investigate the cases against them. It was not easy to convince SBY, but surprisingly, one night he called me and asked me to draft a presidential decree to establish the team. He even allowed me to propose members of the 
independent team.

Finally the independent team was established and named as the 8 Team, because it consisted of eight people, led by the late Adnan Buyung Nasution, also previously a professor in this faculty. I was the secretary of the team. After inviting and interviewing many people, the team concluded within 2 weeks that there were no evidence against Chandra and Bibit. The President finally made a public statement that the case against the two commissioners should be settled 'out of the court', meaning no legal prosecution should be carried out against both of them.

Further, to follow up one of the recommendations of the 8 Team, President SBY formed the Task Force to for Eradication Legal Mafia. Judicial corruption was clear from our investigation of Chandra and Bibit's case. I therefore recommended the President establish an ad hoc task force under his direction to combat the judicial mafia. Actually, I was not confident the President would accept my suggestion but one day he invited me in a meeting in Cikeas, and told me that he wanted to put the battle against judicial mafia as the number one priority for the 100 Days Program with which he wished to start his $2^{\text {nd }}$ term. Then, at another meeting in the State House, he instructed me to draft the Presidential Decree to set up the task force. It existed for two years, from 2009 to 2011, and was led by a very effective figure, Kuntoro Mangkusubroto. I was again the secretary of this ad hoc team.

Unfortunately, the authority of the team was limited, because to have the power as legal enforcer, it needed a statute as a legal basis, not just a presidential decree. However, we managed to increase public awareness of the need to fight against the judicial mafia. One of the cases widely covered by the media was the Gayus Tambunan case. I found this corrupt tax official in Singapore, where he was a fugitive, and persuaded him to come back to Jakarta. It turns out that the case was a very high profile one. After returning from Singapore, I directly requested to meet the President in Cikeas and reported to him classified information that I learned from Gayus about the identity of the companies he worked with to illegally reduced their tax bills.

I knew that the owner of the companies was very upset and unhappy that Gayus's case had blown up in this way. In one occasion, he was spoke directly to me and made his unhappiness very clear. I believe this strong political and business figure managed to influence the decision-making process such that the anti-judicial mafia Task 
Force was not extended beyond its original two years as we had planned it would.

In 2012, when I was the Deputy Minister of Law and Human Rights, another conflict took place between KPK and corrupt policemen, in relation to a corruption case investigated by KPKagainst Djoko Susilo, a two-star general. This time none of the commissioners of KPK were legally attacked, but Novel Baswedan, a very senior investigator of KPK, who had led Djoko's case, was named a suspect in a torture case. Accordingly, the case against Novel was widely seen as another attempt to criminalize the KPK. It became the second gecko versus crocodile conflict.

Although I was not his special legal advisor anymore, President SBY called me and asked my advice on the second conflict. He specifically asked me who had the jurisdiction to handle Djoko's case, because the police argued that they had the authority over the case, not the KPK. I explained to SBY that KPK clearly has the jurisdiction over the police based on the KPK Law itself. After carefully reading the law, President SBY agreed with me and made a public speech that the KPK should continue to handle the corruption case against Djoko. SBY further indicated that he instructed the police to halt the case against Novel Baswedan.

The two gecko versus crocodile conflicts clearly showed SBY's support for the KPK. I should mention, however, that his support might also have been influenced by public pressure. The two conflicts were widely covered by the media-print and electronic. They were therefore, monitored by President SBY as important issues to which he needed to pay more attention.

\section{PRESIDENT SBY AND PUBLIC PERCEPTIONS}

Another factor I think important is the influence of public perceptions on the anti-corruption agenda during SBY's presidency. SBY always monitored the media-including social media-, particularly as regards the anti-corruption agenda. His decision would, therefore, be influenced not only by political consideration but also public perceptions.

In terms of public perception, the two "gecko versus crocodile" conflicts were clear examples of how a strong public campaign could influence President SBY's decision making. I know that, in making 
decisions, he tried to listen to as many people as possible. I understand that for the first gecko versus crocodile conflict in 2012, SBY ordered an independent polling company to conduct a survey on popular aspirations for the case against the two commissioners of KPK. The survey result was definitely a key source of information used by SBY to make his decision in favor of KPK.

However, it is important to understand that not all of SBY's decisions were decided by all public pressure. In relation to the death penalty for example, although there was strong public support to execute drug dealers, SBY was very careful in making decisions on clemency. In fact, at one meeting I attended, he clearly mentioned that he is not in favor of death penalty. Pak SBY could not publicly mention this position, however, because the death penalty was held to be constitutional by the Constitutional Court. Hence, despite strong support from the public, SBY instead deliberately postponed some executions.

\section{CONCLUSION}

My six years as President SBY's special advisor and deputy minister was truly an invaluable experience. I was able to see firsthand how regulations are developed and applied in real politics, especially in relation to anti-corruption cases. My conclusion is not unique - the Indonesian experience is similar to that of other countries who have corruption as one of the main problems they face. No president has a magic spell that can easily make the corruption disappear. No president can effectively run the country without the presence of strong constitutional power, enough political support and the presence of effective control mechanisms.

In Indonesia, post-reformasi presidents, including SBY, faced major challenges in delivering anti-corruption reforms. The constitutional reforms limited presidential powers; political support of more than $50 \%$ of the parliament cannot easily be won or be maintained; and the sources of control - that is, checks and balances, are very strong and come from many directions. Therefore, President SBY's anti-corruption agenda has had some achievements but also failures. One of the reasons for this is that the political elites did not fully support the war against corruption. Some of the parties' leaders were even investigated and jailed by KPK, including the previous chair 
and treasurer of Democrat Party, the party of President SBY himself

SBY therefore tried very hard to balance a lack of political support and the necessity of combating corruption. This is why his fight against corruption achieved some success, but left many unresolved challenges. The dilemma of any president in the current politics of Indonesia, including SBY, is how to combat corruption effectively, and at the same time keep strong and stable political support so as to be able to deliver significant economic growth for the people's prosperity. Regrettably, to combat corruption is probably to point the gun at the very politicians or businessmen who politically or financially support the president himself. And sometimes they fight back, and therefore, the gun backfires! 